\title{
Biología y métodos diagnósticos del virus de la hepatitis $C$.
}

Revisión

Ivonne Gómez-Cordero¹, Milagros Álvarez-García².

${ }^{1}$ Laboratorio de Síntesis de Péptidos, Centro de Inmnoensayo. ${ }^{2}$ Departamento de Control de Calidad Analítico, Centro de Inmunoensayo, Habana, Cuba.

\section{RESUMEN.}

La hepatitis $\mathrm{C}$ se ha convertido en la forma más común de hepatitis post-transfusional, y es la responsable de más del $70 \%$ de las enfermedades virales del hígado. Su agente etiológico es el virus $\mathrm{C}$ y su transmisión se produce por vía parenteral y productos contaminados por sangre. El periodo de incubación es de 5 a 12 semanas, los anticuerpos aparecen tardíamente alrededor de las 20 semanas y pueden persistir toda la vida. La mayoría de las personas con hepatitis $\mathrm{C}$ no tienen síntomas y llevan vidas normales. El análisis filogenético de numerosos aislamientos del virus de la hepatitis $\mathrm{C}$ indican la presencia de distintos niveles de variabilidad genética: genotipos, subtipo y cuasiespecies. Raramente es diagnosticada hasta la aparición de sus complicaciones crónicas. Después de la secuenciación del genoma y la descripción del virus mediante técnicas de ingeniería genética se hizo posible el diagnóstico de laboratorio de la infección por el virus de la hepatitis C. Los ensayos han ido evolucionando hasta los de tercera generación que detectan los anticuerpos del núcleo y los antígenos de las regiones no estructurales NS3 y
NS5. (Rev Biomed 2003; 14:253-268)

Palabras clave: Virus de la hepatitis C, métodos diagnósticos, hepatitis viral.

\section{SUMMARY.}

Biology and diagnostic methods of the hepatitis C virus.

Hepatitis $\mathrm{C}$ has become the most common form of post-transfusional hepatitis, and is responsible for over $70 \%$ of the viral illnesses of the liver. The etiological agent is the virus $\mathrm{C}$ and its transmission occurs by parenteral via and contaminated blood products. The window-period phase ranges from 5 to 12 weeks, antibodies appear after about 20 weeks and they can persist for a lifetime. Most people with hepatitis $\mathrm{C}$ do not have symptoms. The phylogenetic analysis of numerous isolations of hepatitis $C$ virus indicates the presence of different levels of genetic variability: genotypes, subtypes, and quasispecies. It is rarely diagnosed before chronic complications appear. Laboratory diagnosis of hepatitis $\mathrm{C}$ virus

Solicitud de sobretiros: Ivonne Gómez-Cordero, Centro de Inmunoensayo, Calle 134 y Ave. 25, Cubanacán, Playa, Ciudad de la Habana, Cuba. E-mail: ivonchi@infomed.sld.cu

Recibido el 9/Mayo/2003. Aceptado para publicación el 21/Julio/2003.

Este artículo está disponible en http://www.uady.mx/sitios/biomedic/revbiomed/pdf/rb031446.pdf

Vol.14/No.4/Octubre-Diciembre, 2003 


\section{Gómez-Cordero, M Álvarez-García.}

infection became possible after genome sequencing and virus description by means of genetic engineering techniques. Assays have been developed up to the third generation and detect the antibodies of the nucleus and the antigens of the NS3 and NS5 nonstructural regions. (Rev Biomed 2003; 14:253-268)

Key words: Virus de la hepatitis C, métodos diagnósticos, hepatitis viral.

\section{Introducción.}

El término hepatitis, proveniente del griego hepar, que significa hígado, fue utilizado por primera vez por Bianchi en 1710 y se refiere a todas aquellas enfermedades que pueden de una forma u otra inflamar el hígado (1). La causa más frecuente que provoca hepatitis es una infección vírica, aunque también puede ser producida por agentes químicos o venenos, el efecto de alguna medicina, anestésicos, drogas, bacterias o toxinas bacterianas, enfermedades producidas por amibas, infecciones parasitarias, por la existencia de litiasis en la vesícula, entre otras $(1,2)$. De ahí que las hepatitis se dividan en infecciosas y no infecciosas. La padecida por la mayoría de los pacientes es la de tipo infecciosa.

La hepatitis vírica típica en los humanos es producida debido al efecto de varios tipos de virus, las formas más comunes son la hepatitis por el virus $\mathrm{A}$ (VHA), la hepatitis por el virus B (VHB) y la hepatitis por el virus $\mathrm{C}$ (VHC), que anteriormente se conocía como hepatitis no $\mathrm{A} /$ no $\mathrm{B}$, y la única relación entre ellas es que todas afectan al hígado (1).

La hepatitis causada por el virus de la hepatitis $\mathrm{C}$ (VHC) se ha transformado en uno de los principales problemas de enfermedades infecciosas emergentes (3).

\section{Descubrimiento del agente causante del virus de la hepatitis $\mathbf{C}$.}

En la década de 1940, existían por lo menos dos tipos de hepatitis, la A y la B $(4,5)$, pero no fue hasta la década del 70 que se logró con marcadores serológicos, identificar la causa de la enfermedad de ambos y distinguirlos clínica y serológicamente.

En 1974, Prince y col., en el New York Blood Center reportaron que el $25 \%$ de los pacientes sometidos a cirugía cardiovascular desarrollaron una hepatitis post-transfusional y el $18 \%$ de ellos dieron negativo a los marcadores de ambos virus y con características clínicas diferentes (6). Por este motivo, sugieren la posibilidad de un nuevo tipo de virus y proponen identificarlo como virus de la hepatitis tipo C (VHC). Sin embargo, fue hasta 15 años después que un grupo de la Corporación Chiron, en Emeryville, California, a través de métodos de biología molecular e inmunológicos, logró identificar el(los) agente(s) causantes del VHC $(7,8)$. Ellos construyeron una "secuencia" de ADN complementario (cDNA), del plasma que contenía el agente no caracterizado de la hepatitis no-A no-B (HNANB). Después, buscaron en la biblioteca de ADN y aislaron un clon de cDNA que codificaba un antígeno asociado específicamente con HNANB y se encontró que este clon derivaba del genoma de un agente similar a Togaviridae o Flavivirus. Este nuevo agente fue nombrado hepatitis $\mathrm{C}(7,8)$, el virus causante de la mayoría de las hepatitis post-transfusionales $(9,10)$.

\section{Progresión y rasgos clínicos de la enfermedad.}

El mecanismo exacto por el cual este virus causa hepatitis aún no es bien conocido. Existen algunos elementos que permiten plantear que se trata de un virus citopático, pero el mecanismo del daño no es sólo citopático (no todos los individuos tienen daño hepático), sino que también puede ser inmunológicamente mediado (11).

Cuando alguien se infecta con el virus de la hepatitis $\mathrm{C}$, éste invade el organismo y primariamente reside en la células hepáticas (hepatocitos). Una vez producida la infección, el cuerpo comienza a producir anticuerpos para destruirlo; sin embargo, la mayoría de las veces los anticuerpos no logran identificar adecuadamente al virus y la infección permanece a largo plazo. De hecho, gran parte de las personas infectadas con este virus no saben que lo están debido a que no experimentan síntomas (2).

Después de la exposición al virus, el período de

\section{Revista Biomédica}


Virus de la hepatitis $C$.

incubación oscila entre 2 y 26 semanas. La fase inicial de la enfermedad por el VHC se denomina infección aguda, la que normalmente desaparece después de 2-12 semanas. El $80-85 \%$ de las personas inicialmente infectadas no eliminan el virus de su organismo y quedan crónicamente infectadas (la infección no desaparece en un plazo de seis meses), casi todas libres de síntomas y con una vida normal. Sin embargo, en el $10-25 \%$ la enfermedad sigue progresando durante un período de 10-40 años, lo cual puede ocasionar graves daños hepáticos como cirrosis (20\%), cáncer de hígado (carcinoma hepato-celular $4 \%)(1,3,12)$ e incluso la muerte.

Muchas personas sienten pocos o ningún síntoma durante la fase aguda de infección, la mayor parte con el VHC crónico tampoco presenta síntomas y lleva una vida relativamente normal $(1,3)$. Sin embargo, otras personas experimentan síntomas leves semejantes a los de la gripe, tales como náuseas, fatiga, fiebre, dolor de cabeza, vómitos, pérdida de apetito, dolor abdominal y dolores musculares o articulares. Algunas personas llegan a sentir síntomas similares a los de una gripe fuerte, acompañados de ictericia (donde la piel y la orina se vuelven amarillentas) y decaimiento $(1,13)$.

\section{Prevalencia, transmisión, grupos de riesgo y terapia del virus de la hepatitis $C$.}

El VHC está presente en todos los países y la prevalencia de la enfermedad varía ampliamente de uno a otro, desde un $0.5 \%$ en Suecia y Suiza, $1 \%$ en Francia, hasta un 5\% en países desarrollados (14). Sin embargo, es mucho menor en los países industrializados que en los países en vías de desarrollo (1). Afecta por igual a todas las razas, sexos y edades.

Alrededor de 170-200 millones de personas en el mundo están infectadas con el virus, incluyendo 9 millones en Europa y 4,5 millones en EE. UU., con cerca de 180,000 casos nuevos por año en Estados Unidos y 350,000 en Japón $(1,3,15)$. Posee el potencial de ser la próxima epidemia global.

Estudios que involucraron la inoculación experimental evidenciaron la presencia de un virus de la familia Togaviridae asociado a la transmisión del
VHC (16,17), cuya infección ocurre mayoritariamente luego de la exposición directa parenteral o percutánea $(1,3,18)$.

En el 60-70\% de los casos, la transmisión es parenteral, por transfusiones de sangre y el uso compartido de material para drogas tanto intravenosas como de otro tipo (jeringas, pajas para inhalar, cucharas, torniquetes, etc.), las agujas contaminadas utilizadas para hacer tatuajes, la perforación del cuerpo y la acupuntura $(1,3,14,18)$. Un pequeño porcentaje de personas (1-3\%) puede contraer el virus mediante prácticas sexuales sin protección. La transmisión perinatal de madres infectadas por el VHC a sus hijos, antes o durante el parto, es menor del 5\%.y entre el 30-40\% de los casos aún no han sido identificados los factores de riesgo $(1,14,15,19)$. El uso compartido de objetos personales tales como cuchillas de afeitar, cepillos de dientes y cortaúñas es menos peligroso, pero aun así es una vía potencial de transmisión. El virus no puede transmitirse por contactos casuales tales como estornudos, abrazos, tos, ni por compartir utensilios de comida o vasos (1).

Es por eso que los grupos de mayor incidencia son los receptores de sangre o sus derivados, los usuarios de drogas intravenosas, los pacientes en hemodiálisis con diálisis renal, los hemofílicos, así como los profesionales del sistema médico debido a los accidentes por punción con agujas y por estar expuestos a situaciones inevitables que dan lugar al contacto directo con la sangre de personas infectadas $(14,15,20)$. Se ha observado una tendencia a contraer la infección por el VHC en pacientes con muchas parejas sexuales (13).

Debido al uso de la misma vía de transmisión, la coinfección por el VHC y el VIH es muy frecuente, donde la mayoría de los pacientes infectados por el VIH son o han sido usuarios de drogas por vía parenteral (UDVP). Según un estudio de EuroSIDA, más del $75 \%$ de los UDVP con infección por el VIH están infectados por el VHC (18).

Las vacunas para el VHC van a ser difíciles de desarrollar debido a los distintos genotipos del virus y a su capacidad de cambiar o mutar durante la infección $(1,21)$. 


\section{Gómez-Cordero, M Álvarez-García.}

Para una correcta terapia y estrategias preventivas es necesario conocer la virología del VHC y su mecanismo de persistencia.

Hasta 1998 el único tratamiento aprobado para el VHC era la monoterapia con interferón, y actualmente es la politerapia de interferón más ribavirina. Entre las nuevas terapias que se están desarrollando para detener o inhibir la replicación del VHC se encuentran los inhibidores de la helicasa, los inhibidores de la proteasa, las ribozimas y las interleucinas (1).

Los tratamientos farmacéuticos aprobados son:

Interferón: producto elaborado genéticamente que se basa en una serie de proteínas naturales del sistema inmunológico. Alrededor del 50-60\% de los pacientes responde a la monoterapia de interferón; sin embargo, una vez que se suspende el tratamiento la mayoría recae. Se calcula que sólo el 10-20\% de los pacientes tratados llega a mantener el virus a nivel indetectable de forma permanente $(1,22)$.

Ribavirina: medicamento antivírico que se utiliza en politerapia con el interferón (1).

Combinación del interferón estándar (Intron A) y ribavirina en un solo producto (1).

Interferón "pegilado" de acción prolongada, que se inyecta una vez a la semana. Como mantiene un nivel más constante de interferón en la sangre, reduce la capacidad de replicación del VHC. Este tipo de interferón "pegilado" más ribavirina es una terapia más efectiva.

\section{Clasificación del virus de la hepatitis $\mathbf{C}$.}

El VHC se logró describir, caracterizar y diagnosticar antes de su aislamiento, su visualización y la aplicación de las técnicas tradicionales de virología $(11,16)$. Sin embargo, su estructura física permanece esencialmente desconocida debido a los títulos del virus en sangre, inferiores a $10^{6}$ dosis infectivas/mL y a la pérdida de anticuerpos precipitantes capaces de concentrar el virión y hacerlo visible al microscopio electrónico $(9,11,16)$. Hasta la fecha no ha podido ser aislado en cultivos celulares (2).

La clasificación del virus se realizó mediante la comparación de la secuencia nucleotídica del genoma completo con las referidas para otros virus. Mediante el análisis de los perfiles de hidrofobicidad de la poliproteína completa, se predijeron las posiciones de los sitios de corte y la función de las proteínas resultantes y se concluyó que se parecía al género Flavivirus $(10,23)$. Por numerosos experimentos se pudo comprobar que la NS5 se procesa y que la NS1/ E2 corresponde más a una proteína estructural, como la E2 de los Pestivirus $(11,24,25)$. Así mismo, los datos experimentales de gradiente de densidad, la presencia de dos proteínas codificadas por la región NS5, así como la alta homología de sus secuencias nucleotídicas correspondientes a la región no codificante (UTR) ubicada en el extremo 5'no codificante y a la región NS3, indican una mayor relación con éstos (11). Debido a su organización genómica y homología parcial ha sido clasificado en el género Hepacivirus dentro de la familia Flaviviridae $(2,11,18,26)$.

La partícula viral tiene un diámetro entre 30-60 nm $(9,11,12)$. Su extracción a partir de plasma infeccioso mediante disolventes lipídicos (cloroformo) inactiva el virus indicando que los lípidos son una parte esencial de su estructura, presumiblemente de la envoltura; igualmente, el calor, formol y luz ultravioleta terminan con sus propiedades biológicas $(9,11,12$, 15, 19, 20).

El VHC circula de dos maneras: una con el virión intacto y otra formada por la cápsida nuclear con pérdida de la envoltura de lípidos $(9,11)$. Las formas, genómica la cadena positiva y replicativa la cadena negativa del virus, pueden ser detectadas en el tejido del hígado mediante las técnicas de la reacción en cadena de la polimerasa (PCR) y de la hibridación in $\operatorname{situ}(9,11)$.

\section{Genoma del virus de la hepatitis C. Proteínas virales.}

El genoma del VHC está constituido por una cadena simple positiva de ácido ribonucleico (ARN) de entre 9,500-10,000 nucleótidos (9.6 kb), que codifica para una poliproteína de aproximadamente 3,010 aminoácidos y caracterizada por un alto grado de heterogeneidad genética y con un marco de lectura

\section{Revista Biomédica}


Virus de la hepatitis $C$.

visible (ORF) (2, 9-11, 13, 16, 20-23, 25-32).

El genoma está precedido por una región no codificante $5^{\prime}$ (UTR) de 42 bases, altamente conservada y resistente a la desnaturalización y seguida por una región no codificante $3^{\prime}$ (UTR) de 27 bases con una secuencia de poli(A) (adenina) en el extremo $3^{\prime}(10,12,13,16)$.

La poliproteína puede ser fragmentada, por calor o proteasas virales, en al menos nueve proteínas funcionales (33). La porción amino terminal forma la proteína estructural (región 5 terminal) y se divide en tres proteínas estructurales $(\mathrm{C}, \mathrm{E} 1, \mathrm{E} 2)$, mientras que la carboxilo terminal (región 3’terminal) da lugar a varias enzimas virales y seis proteínas no estructurales (NS2, NS3, NS4a, NS4b, NS5a, NS5b) (12,23,32$35)$. El orden y la nomenclatura de los productos procesados en la proteína precursora del VHC es: $\mathrm{NH}_{2}$-C-E1-NS1/E2-p7-NS2-NS3-NS4a-NS4b$\mathrm{NS} 5 \mathrm{a}-\mathrm{NS} 5 \mathrm{~b}-\mathrm{COOH}$ (11) (figura 1).

\section{Región 5'no codificante del virus de la hepatitis C.}

El extremo 5’ del genoma está compuesto por una región no codificante, comprendida entre los nucleótidos 1-342 (9,13). Es altamente conservada entre aislamientos del mismo grupo (98\%) y entre aislamientos de diferentes grupos (93\%) y está implicada en la regulación de la replicación del genoma viral o en la expresión de los genes $(2,11,12,26)$.

\section{Región estructural del virus de la hepatitis $\mathbf{C}$.}

La proteína del núcleo (C), de 16-22 kDa, comprendida entre los nucleótidos 342-915. El gen C codifica una proteína de unos 191 aa. que forma la nucleocápside, se denomina p22 (antígeno c22) (11). Presenta alto contenido de aminoácidos básicos (arginina y lisina) en su extremo amino y un epítopo inmunodominate localizado en la región $\mathrm{N}$-terminal y con actividad ARN de enlace $(9,11,16,36)$. Es la región estructural más conservada y contra la que mayor reactividad global se ha encontrado en los sueros de portadores, de ahí su importancia como componente de los sistemas diagnósticos (11).

Glicoproteína de la envoltura del virión (E1), de 32-35 kDa, comprendida entre los nucleótidos 915$1491(9,16,29)$. E1 es el responsable de una glicoproteína de 192 aa. (antígeno gp33). Se han localizado al menos 2 epítopos antigénicos potenciales, entre los aminoácidos 210-233 que es una secuencia variable y entre 315-327 que es un dominio altamente conservado (37). El extremo carboxílico es hidrofóbico y posee dos secuencias homólogas a

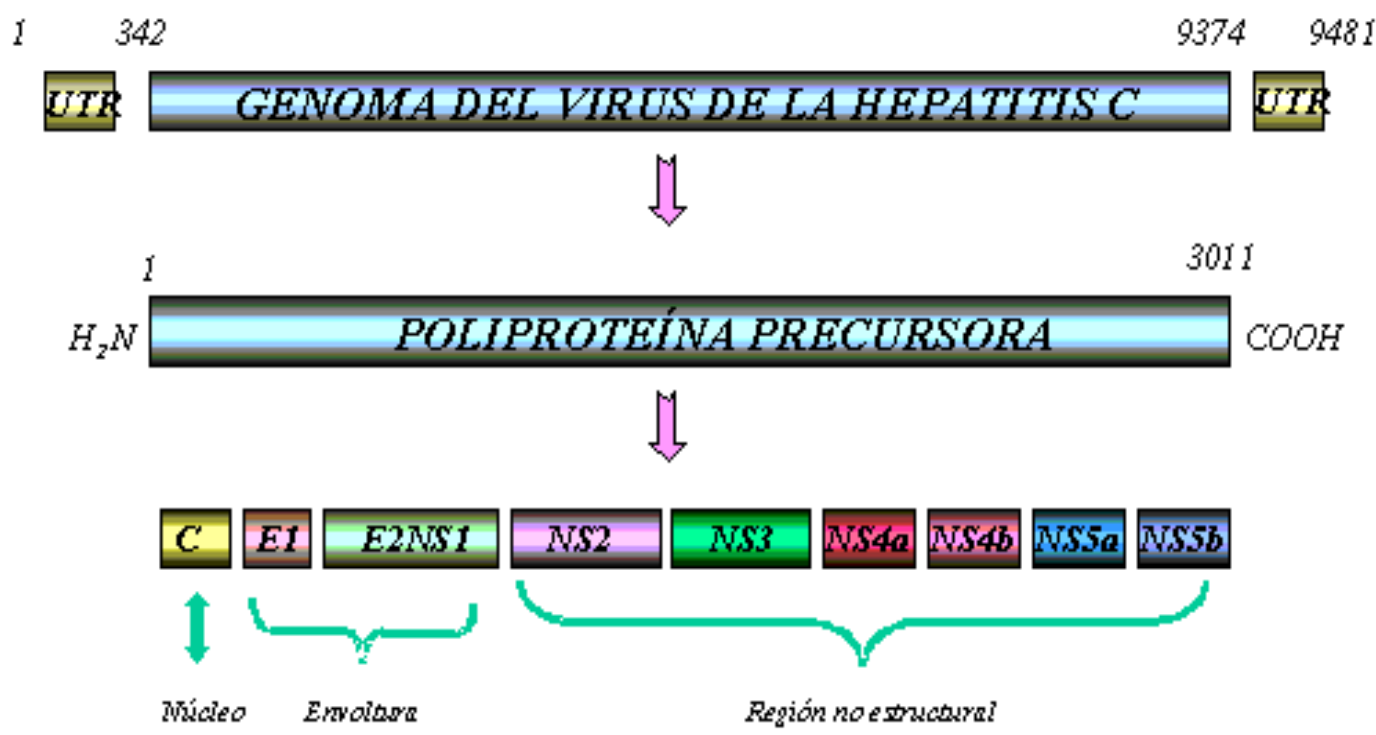

Figura 1.- Genoma del virus de la hepatitis C. 


\section{Gómez-Cordero, M Álvarez-García.}

segmentos transmembranales (11).

Glicoproteína de la envoltura (E2/NS1), de 5872 kDa, comprendida entre los nucleótidos 1491 y 2769. Responde de la traslación de otra glicoproteína de 327 aa. (antígeno gp70) y contiene 11 sitios de glicosilación (11). Es una región hipervariable y de evolución rápida $(9,16,20,29)$. Entre los residuos 484499 y 554-569 tiene dos regiones antigénicas altamente conservadas entre los diferentes tipos de VHC (38). El peso molecular varía, debido a que la proteína presenta dos tipos de procesamiento, en uno la proteína se mantiene intacta (del aminoácido 384 al 810) y en el otro se produce un corte por una peptidasa entre los aminoácidos 746 y 747, que da lugar a una E2 truncada y a una proteína denominada p7 (11).

Las glicoproteínas (E1 y E2) juegan un papel importante en la patofisiología del virus (37). El análisis de las cadenas de todos los VHC aislados revelan que ambas se caracterizan por una marcada variabilidad, incluso dentro de un mismo individuo, especialmente en dos subregiones hipervariables (RHV1 y RHV2) localizadas en la región E2/NS1 $(9,11,16)$. Cuando se expresan juntas en vectores virales, las proteínas E1 y E2 se glicosilan y forman un heterodímero, que es reconocido por la mayoría de los pacientes infectados con el virus. Esto indica que este heterodímero puede ser importante para la conformación adecuada de los epítopos antigénicos (11). Esta región posee un "motivo estructural", entre los aminoácidos 401-406 ó 407, que es inmunogénico y conservado entre los diferentes aislamientos y que es útil para el tratamiento y diagnóstico de VHC (39). En los diferentes aislamientos el porcentaje de homología de la región estructural del virus es entre 74-92\%, siendo la región del núcleo la más conservada (81-88\%) y la región E1, la menos conservada $(53-69 \%)(9,13)$.

\section{Región no estructural del virus de la hepatitis $\mathbf{C}$.}

Esta región incluye proteasas con actividad helicasa y replicasa, ARN polimerasa dependiente de ARN y otros factores de transcripción con función biológica desconocida (16).
El proceso proteolítico de la región no estructural es mediado por dos proteasas virales: proteasa NS23, que rompe la unión NS2/3, y la proteasa NS3.serina dependiente, que es la responsable de procesar los sitios NS3/NS4a, NS4a/b, NS4b/5a y NS5a/5b (figura 1).

La proteína NS2 es un polipéptido de transmembrana de $23 \mathrm{kDa}$, comprendida entre los nucleótidos 2769-3360 (11,28), con su extremo carboxilo traslocado en el lumen del retículo endoplasmático y el extremo amino localizado en el citoplasma. Posee una región muy inmunogénica y altamente conservada en los diferentes aislamientos del VHC entre los residuos 960-975 (40). Su función no está totalmente definida, pero participa en el ensamblaje del virión y forma parte del complejo de replicación junto con la NS5a y NS5b (11).

La proteína NS3, comprendida entre los nucleótidos 3360-5313, es soluble y de 70 kDa (11). Presenta dos actividades enzimáticas, una ATPasa helicasa, indispensable para la replicación del ARN $(11,16,28,41-44)$, y la otra similar a la de las proteasas dependientes de serina, que realiza cortes en cis y trans, y da lugar a un procesamiento proteolítico del resto de la región no estructural en NS4a, NS4b, NS5a y NS5b $(11,45,46)$. Presenta una secuencia de 14 aminoácidos altamente similar al sitio inhibidor de la proteína cinasa cAMP-dependiente (46).

La proteína NS4 se procesa en NS4a de $8 \mathrm{kDa}$ (entre los nucléotidos 5313 y 5475) y NS4b de 27 kDa (5475-6258), ambas muy hidrofóbicas y asociadas a la membrana (11). Su función no es totalmente conocida, pero se le atribuye que forma parte del complejo de replicación viral, que NS4a junto con NS3 forman un complejo con actividad proteolítica similar a la quimotripsina y, además, que la presencia en el extremo 3' de un sitio interno de entrada al ribosoma, seguido de un marco de lectura abierto, podría acelerar la traducción de la replicasa codificada por la NS5 (11). Esta región comprende un fragmento 5-1-1, que contiene sitios de unión a los anticuerpos inmunodominantes (16,28). Posee dos regiones de gran antigenicidad, comprendidas entre

\section{Revista Biomédica}


Virus de la hepatitis $C$.

las regiones 1691-1708 y 1710-1728, altamente variables entre las diferentes variantes de VHC (los tipos 1, 2 y 3 sólo poseen una analogía de 50-60\%) (47).

La proteína NS5 codifica para dos proteínas, la NS5a de 56-58 kDa (6258-7602) y la NS5b de 68$70 \mathrm{kDa}(7602-9375)$. El producto génico de la NS5a da lugar a dos proteínas: una de $56 \mathrm{kDa}$ y la otra de $58 \mathrm{kDa}$, y la NS5b exhibe actividad ARN polimerasa dependiente de ARN (RdRp), indispensable para la replicación del genoma viral $(44,48)$. Su mayor antigenicidad es entre los residuos 2284-2329 pertenecientes a NS5a y entre 2584-2599 y 29442959 de NS5b $(16,40)$. Estas secuencias son variables entre los diferentes tipos del VHC (40). Entre los codones 2209 y 2248 de determinados subtipos hay una región resistente al tratamiento con interferón (11).

El porcentaje de homología de la región no estructural entre diferentes aislamientos es de 71-78\%, siendo NS5 la menos conservada $(56-72 \%)(9,13)$.

Secuencia 3 ' terminal del virus de la hepatitis $\mathbf{C}$.

El genoma culmina en una secuencia 3 'terminal no codificante, pequeña, de alrededor de 200 nucléotidos (9375-9419), rica en uridina (11), conservada entre los diferentes tipos del VHC (52, B,D) e implicada en la replicación genómica $(11,50,51)$. Consta de 4 elementos (cadena positiva 5'a $\left.3{ }^{\prime}\right):$

(1) Una secuencia corta con significativa variabilidad entre genotipos.

(2) Una zona poli (U).

(3) Una región de polipirimidinas, rica en uracilo con algunas citocinas.

(4) Una secuencia de 98 bases, que forma una estructura de tallo y anilla en el extremo $(24,55)$.

Para discriminar entre especies, subespecies y cadenas de VHC las regiones más apropiadas por orden son: E2, NS2, NS5b, E1, NS4a, NS4b y NS5a, las regiones 5 no codificada, núcleo y NS3 no son tan efectivas para la diferenciación (53).
Genotipos y subtipos del virus de la hepatitis $\mathbf{C}$.

El análisis filogenético de numerosos aislamientos de VHC indica la presencia de distintos niveles de variabilidad genética: genotipos (material genético del virus), subtipo y cuasiespecies.

Aunque se han identificado gran cantidad de genotipos, con diferencias sustanciales en la secuencia y de efectos inmunológicos no bien comprendidos (27,54-58), el sistema de clasificación que se ha favorecido es el de Simmonds en 1993 (11), donde el VHC ha sido clasificado en seis tipos mayoritarios (del 1 al 6), con homología del 60-70\% y dentro de cada uno de éstos en subtipos a, b, c, d, e, f, g, h, i, j y k, con homología del 78-88\%, aunque se están descubriendo nuevos subtipos. (1-3,18,26). Además, debido a la incapacidad de corregir errores de la RNA polimerasa viral, en cualquier individuo infectado el RNA viral no está presente como una secuencia única, sino como un conjunto de secuencias muy parecidas, agrupadas alrededor de una secuencia mayoritaria, lo que se conoce como cuasiespecie (26).

La frecuencia de los diversos genotipos varía de un país a otro, la literatura indica que la distribución y prevalencia de los genotipos se presenta en forma diferencial dependiendo de la región geográfica $(1,18,25,30,59-60)$. Los genotipos también han sido asociados a la diferente respuesta al interferón (IFN) y a la combinación IFN/ribavirina (3). El significado clínico de los genotipos del VHC ha sido muy discutido, pero de forma general los genotipos la y $1 \mathrm{~b}$ son los de peor pronóstico, tanto en lo que respecta a la evolución a cirrosis o a hepatocarcinoma como en la respuesta al tratamiento con interferón y ribavirina $(1,18)$.

Existen secuencias específicas del núcleo, E1 y NS5, (4-7, 9-11), y subtipos de los tipos 1 (1d, 1e, 1f y $1 \mathrm{~g}) ; 2$ (2e, 2f, 2g, 2h, 2i, 2k y 2l); 3 (3g) y 4 (4k, 41 y $4 \mathrm{~m}$ ) que son útiles para el diagnóstico y el incremento de la sensibilidad de los ensayos de detección del virus $(47,61)$.

La infección con dos o más genotipos diferentes es común en pacientes con hemofilia y en aquellos que reciben frecuentes transfusiones (25).

La determinación del genotipo viral es una

Vol.14/No.4/Octubre-Diciembre, 2003 


\section{Gómez-Cordero, M Álvarez-García.}

herramienta muy útil en estudios de transmisión del VHC, de la epidemiología molecular, la patogénesis, el diagnóstico serológico, la historia natural y el tratamiento de la infección por el VHC $(13,25,26,60)$. La variabilidad geográfica en su distribución, así como la asociación de determinados genotipos con factores de riesgo específicos ha dado lugar a estudios epidemiológicos a gran escala (26).

\section{Diagnóstico de la hepatitis $\mathbf{C}$.}

La hepatitis $\mathrm{C}$ es una enfermedad que permanece desconocida y es raramente diagnosticada hasta la aparición de sus complicaciones crónicas. A partir de 1989 después de la secuenciación del genoma y la descripción del virus mediante técnicas de ingeniería genética (7) se hizo posible el diagnóstico de laboratorio de la infección por el VHC.

Para la detección o diagnóstico de la infección por el VHC y el estado de progresión de la enfermedad, existen diferentes pruebas (1). Los ensayos serológicos, que detectan anticuerpos al VHC (anti-VHC), se subdividen en ensayos de escrutinio como los inmunoenzimáticos, principalmente los "Enzyme Linked Immunosorbent Assay" (ELISA) (20), que usan anticuerpos policlonales o monoclonales (para detectar antígenos) o virus completos, péptidos sintéticos o antígenos recombinantes (para detectar anticuerpos) $(12,25,62)$ y ensayos suplementarios como los "Recombinant Immunoblot", entre ellos el de tercera generación para $\operatorname{IgG}$ (RIBA 3.0).

Los ELISA de tercera generación son útiles en la detección de las regiones estructural y no estructurales del VHC, de la proteína GOR que se ha visto que está presente en algunos pacientes con VHC (63) y son sensibles y específicos para el estudio en pacientes con trasplante renal (64). En el diagnóstico del VHC en pacientes hemodializados, es útil el empleo de un ELISA con un péptido quimérico obtenido de la unión mediante Glicina-Glicina (GlyGly) de dos de los péptidos sintéticos de las regiones NS4 y NS5 y proteínas recombinantes (núcleo y NS3) (65).

Las pruebas confirmatorias de anticuerpos para conocer qué antígenos virales son los responsables de la reactividad obtenida en una prueba ELISA, se realizan sobre un soporte de nitrocelulosa al que se adhieren péptidos en diferentes lugares, la adición de la muestra y su revelado pondrá de manifiesto la existencia de anticuerpos (25).

En casos de hepatitis aguda, problemas en la interpretación de los resultados de los ensayos de ELISA, o pacientes inmunodeprimidos, es necesario analizar el ARN del VHC (27).

Ensayos moleculares detectan, cuantifican y caracterizan el genoma del VHC (66). Mediante técnicas moleculares es posible incluso establecer el origen común de brotes epidémicos. Ello requiere, una vez establecido el genotipo, la amplificación y secuenciación de una región variable, y el análisis filogenético de las secuencias problema y los controles adecuados. Mediante estas técnicas se ha podido confirmar casos de transmisión materno-fetal, sexual y nosocomial (26) y es el mejor método para detectar el ARN del virus en pacientes inmunosuprimidos después de trasplante de hígado (67).

Los ensayos que permiten detectar, clonar y secuenciar genomas virales, son más sensible que las pruebas convencionales aun en pacientes con niveles bajos del ARN viral y permiten la detección precoz del virus $(11,13)$. Sin embargo, son altamente costosos, muy sofisticados, requieren de un seguimiento cuidadoso para reducir la contaminación, una correcta colección y almacenamiento de las muestras y con problemas especiales en la amplificación, debido a la variabilidad de la secuencia $\operatorname{del} \operatorname{ARN}(9,11)$.

El diagnóstico molecular incluye (1):

a) La detección cualitativa o cuantitativa del RNA viral en suero, plasma o tejido mediante técnicas de PCR o RT-PCR competitiva (SuperQuant, NGI, CA) o no (Amplicor HCV y Amplicor HCV Monitor, Roche Molecular Systems); de amplificación de señal por DNA ramificado (bDNA) (QuantiplexHCV RNA, Bayer Diagnostics), método quimioluminiscente, sencillo y rápido, que se basa en que la región 5' (UTR) del ARN viral es híbrida con una sonda específica, a la que se unen moléculas

\section{Revista Biomédica}


Virus de la hepatitis $C$.

quimioluminiscentes que permiten amplificar la señal, en vez del genoma $(11,12)$; de RT-PCR en tiempo real (Taqman, Roche Molecular Systems) $(9,11)$; mediado por transcripción (TMA) que amplifica secuencias especificas del RNA viral y los PCR de única etapa (ss-PCR), uno basado en la detección de los productos de PCR por hibridación líquida con una sonda marcada de $\mathrm{P}^{32}$ (ss-PCR isotópico) y el otro un método colorimétrico (ss-PCR colorimétrico) que usa microplacas de hibridación con una sonda específica de ácido nucleico (Amplicor HCV PCR, Roche Diagnostics System), ambos con buena sensibilidad (68). Las pruebas de carga vírica miden la cantidad de virus que circula por la sangre. La más sensible es la del ARN del VHC mediante la RCP, que puede detectar hasta 50 partículas (copias) de virus por cada mililitro de sangre. Las únicas pruebas de carga vírica aprobadas por la FDA son Amplicor y Amplicor Cobalt para el VHC, ambas de Roche (1).

b) La determinación del genotipo/subtipo mediante técnicas serológicas o moleculares. Las pruebas genotípicas se utilizan para determinar qué tipo de VHC se tiene. Esta información es muy útil en estudios de transmisión del $\mathrm{VHC}$, imprescindible para establecer tipo y tiempo del tratamiento antiviral y es el primer paso en cualquier estudio de epidemiología molecular $(1,12)$. Existen diversas técnicas para la determinación del genotipo viral, unas basadas en la amplificación de secuencias (5'UTR, core, NS5b) con cebadores tipo-específicos, o seguidas de hibridación a sondas tipo-específicas, o de análisis de restricción de producto amplificado; y otras basadas en la determinación de anticuerpos frentes a péptidos tipoespecíficos $(12,26,69,70)$. Estas últimas son sencillas $\mathrm{y}$ en pacientes inmunocompetentes tienen buena concordancia con las técnicas moleculares, pero su uso está limitado en pacientes inmunodeprimidos y en el análisis de determinados genotipos. La determinación del genotipo viral es imprescindible para establecer la duración del tratamiento antiviral y es el primer paso en cualquier estudio de epidemiología molecular (26). Para la serotipificación existe un ELISA de detección de anticuerpos específicos de la región NS4 (70). Uno de los métodos más confiables, convenientes, específicos y reproducibles es un RIBA "immunoblot" en tiras, de cinco canales con péptidos serotipo-específicos inmovilizados de la región no estructural NS4 y de las regiones del núcleo de los tipos 1,2 y 3 (69).

c) La determinación de la complejidad de la cuasiespecie viral (26).

Otras pruebas útiles para integrar la presunción diagnóstica de la infección por el VHC son las pruebas funcionales hepáticas. Lo más común es medir la aminotransferasa de alanina (ALT) y la aminotransferasa de aspartato (AST). Muchas personas portadoras del VHC muestran elevaciones ligeras o moderadas de estas enzimas, por lo que éstas suelen ser los primeros indicadores de la presencia del virus. Otras medidas son las de la fosfatasa alcalina (ALK) y las de la gamma-glutamil-transferasa (GGT), los resultados anormales pueden indicar cirrosis y bloqueo del tracto biliar, así como otras anomalías.

\section{Evolución de los ensayos de detección del virus de la hepatitis $\mathbf{C}$.}

En 1989 la compañía norteamericana Chiron clonó el genoma del VHC del plasma de chimpancés infectados con agentes etiológicos de la hepatitis noA, no-B, y obtuvieron por el método de ADN recombinante en levadura una proteína (C100-3) codificada por la región correspondiente a NS4 que contiene la región 5-1-1. Esta proteína recombinante de 363 aminoácidos, fusionada a una molécula de superóxido dismutasa (SOD), fue la base del primer sistema diagnóstico (EIA-1) (11). Estos sistemas de primera generación mostraron baja sensibilidad y especificidad, debido a la alta diversidad genética de la secuencia nucleotídica $(11,13)$ y a que no detectaban anticuerpos en la etapa temprana de la infección.

Esto motivó el desarrollo de sistemas diagnósticos de segunda generación que incorporaron, además de la C100, una proteína recombinante del núcleo del virus (c22), ya que alrededor del 93-95\% de las personas infectadas desarrollan anticuerpos contra la proteína del núcleo (anti-c22c), los que 


\section{Gómez-Cordero, M Álvarez-García.}

aparecen más temprano y continúan presentes por más tiempo (17), y otra de la región no estructural NS3 (c33c) ya que los anticuerpos anti-c33c aparecen primero y con más frecuencia que C100-3 $(11,13)$. Se sustituyó, además, la SOD por la CKS ("citidinmonofosfato-2-ceto-3-desoxi-octanato-sintetasa"). Estos sistemas incrementaron la sensibilidad de detección a $99 \%$ (11).

Actualmente existen ensayos de tercera generación que detectan los anticuerpos del núcleo y los antígenos de las regiones no estructurales NS3 y NS5 (11,13). El siguiente esquema muestra la evolución de los ensayos según Padrón y Morales, 1998 (figura 2).

\section{Ensayos comerciales para el diagnóstico de la hepatitis $\mathrm{C}$.}

Enzymun-Test ${ }^{\circledR}$ Anti-HCV de Boehringer Mannheim Immunodiagnostics (ES 700/ES 607/ES 600/ES 300) (1994). Ensayo inmunoenzimático para la determinación de anticuerpos contra proteínas estructurales y no estructurales del VHC. Es un ELISA tipo "sandwich" en dos pasos con tecnología de estreptavidina (71).
MONOLISA anti-HCV, técnica inmunoenzimática indirecta para la detección de anticuerpos al virus de la hepatitis C. Utiliza una fase sólida con antígenos purificados: dos proteínas recombinantes producidas por Escherichia coli, de clones de la región no estructural del virus (NS3 y NS4) y dos péptidos codificados de la "capside" del genoma (72).

UBIHCV EIA 4.0, ensayo inmunoenzimático cualitativo (EIA) para la detección in vitro de anticuerpos contra el VHC en suero o plasma humano. Utiliza péptidos sintéticos altamente antigénicos de las regiones estructural y no estructurales (NS4 y NS5) (73).

Ensayo Inmunoenzimático Fluorescente (FEIA), ensayo de captura de proteínas, altamente sensible y cuantitativo. Se desarrolló con la utilización de anticuerpos monoclonales (AcM), contra proteínas del núcleo de VHC (74,75). Este ensayo es bueno para la detección y cuantificación de proteínas del núcleo del VHC, muy sensible para detectar pacientes con la infección tipo 2 y juega un papel predictivo en la respuesta ante el interferón $(76,77)$.

Ensayo Quimioluminiscente, método alternativo para la detección de anticuerpos al VHC. Este ensayo

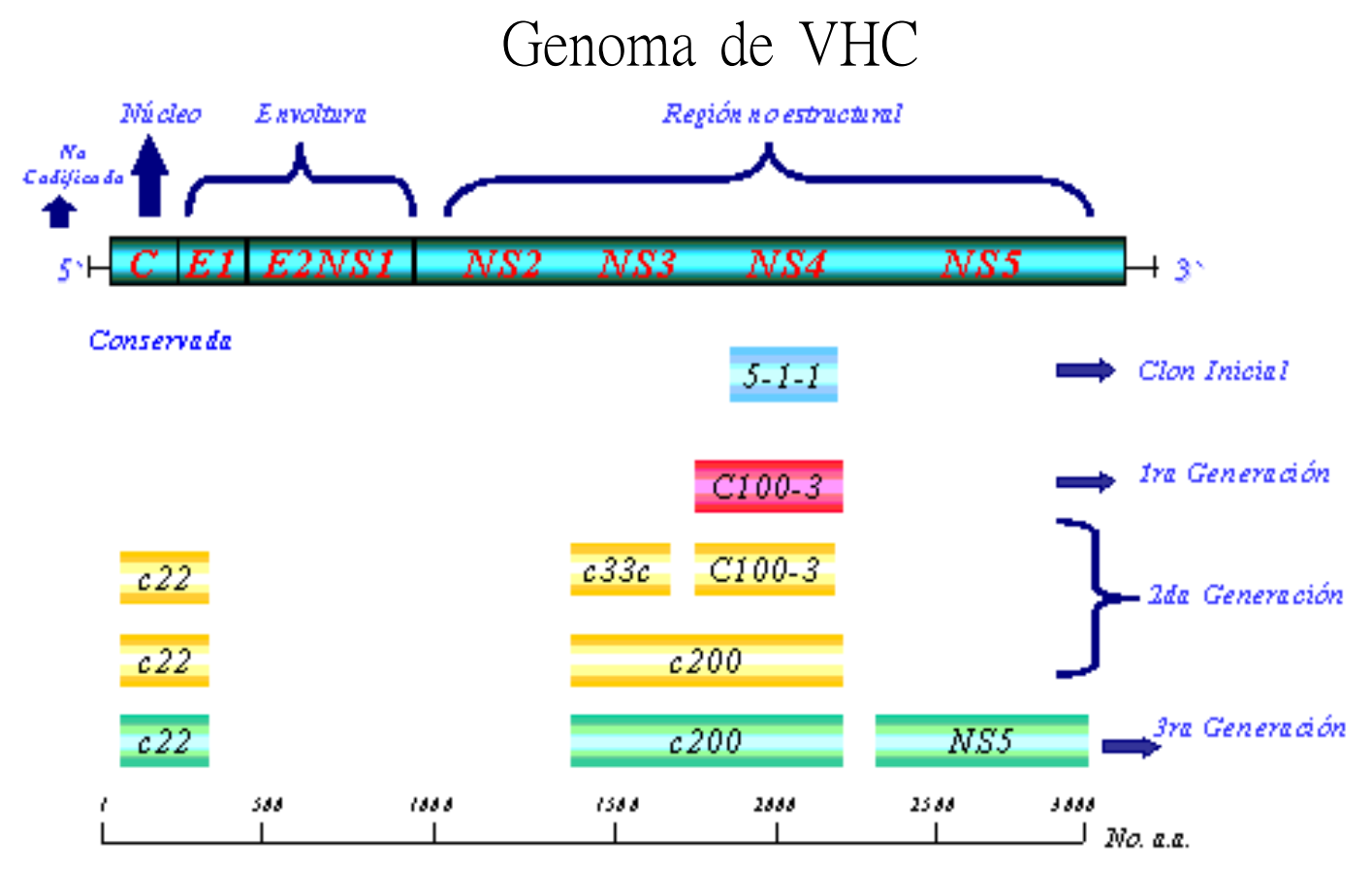

Figura 2.- Evolución de los ensayos de determinación del virus de la hepatitis C.

\section{Revista Biomédica}


Virus de la hepatitis $C$.

tiene $100 \%$ de sensibilidad y $99.9 \%$ de especificidad (78).

AxSYM HCV ${ }^{\circledR}$, ensayo inmunoenzimático de micropartículas (MEIA), para la detección cualitativa de anticuerpos contra las proteínas estructurales y no estructurales del genoma de $\mathrm{VHC}$, en suero o plasma humano. Utiliza las proteínas recombinantes c200 (de los aminoácidos 1192-1931 de las regiones NS3 y NS4, es quimérica de fusión con 154 aminoácidos de la SOD), c22-3 (aminoácidos 2-120, del "core", es una proteína de fusión con 154 aminoácidos de la SOD), HC-34 (239 aminoácidos de la proteína CMPKDO sintetizada en Escherichia coli, 7 aminoácidos de enlace y los aminoácidos del 1-150 de "core") y HC-31 (proteína recombinante quimérica, de fusión con 239 aminoácidos de la CKS de Escherichia coli, 8 aminoácidos de enlace, los aminoácidos 1192-1457 de NS3, los aminoácidos 1676-1931 de NS4 y 10 aminoácidos de enlace agregados en el grupo carboxilo terminal). Los coeficientes de variación intra e inter-ensayo son menores del 6\%, la sensibilidad de 99.69\% y la especificidad de $99.69 \%$ (79).

ABBOT HCVEIA 3.0, ensayo inmunoenzimático, que utiliza los siguientes antígenos recombinantes: HC34 (contiene secuencias de la proteína estructural), HC43 (contiene secuencias de la proteína estructural y de NS3), c100-3 (contiene secuencias de NS3 y NS4) y NS5 (secuencias de NS5). Posee coeficientes de variación inter e intra-ensayo menores del $12.5 \%$ y una especificidad de $99.6 \%$ (80).

RIBA 3.0, ensayo "Recombinant Immunoblot" de tercera generación para la detección de IgG, que en la fase sólida utiliza antígenos recombinantes de la región estructural C22-3 (core) y de las regiones no estructurales NS4 (C100-3), NS3 (C33C) y NS5 $(66,81,82)$.

Murex anti-HCV (Versión III), ensayo inmunoenzimático para la detección de anticuerpos del VHC, en plasma o suero humano. Utiliza antígenos recombinantes de la región estructural ("core"), y de las no estructurales NS3, NS4 y NS5. Su especificidad para muestras de donantes es $99.85 \%$ y en muestras clínicas es $100 \%$ (83).

UMELISA HCV de $3^{\text {ra }}$ generación, utiliza como antígenos de captura péptidos sintéticos y proteínas recombinantes, representativos de la región estructural (péptido del núcleo) y no estructural del virus (péptido quimérico NS4/NS5 y proteína recombinante NS3) (84).

UMELOSA HCV cualitativo, ensayo de amplificación de ácidos nucleicos in vitro, con detección mediante hibridación en Sistema UltraMicro Analítico (SUMA) para la determinación del ARN del VHC en suero y plasma humanos (85).

ORTHO HCV 3.0, ensayo cuantitativo para la detección de anticuerpos al VHC, utiliza los antígenos recombinantes C22-3 ("core"), C200 (NS3/NS4) y NS5, su especificidad es de 99.9\% (86).

Procleix: detección del virus en las primeras fases de la infección. Ensayo de amplificación de ácidos nucleicos que determina la presencia en la sangre de los genotipos conocidos de la hepatitis C (Chiron) (87).

AMPLICOR HCV, es el nombre de la marca bajo la cual se comercializan los productos basados en PCR que ofrece Roche Molecular Systems. Tienen dos tipos de pruebas: pruebas semi-manuales en formato de microplacas: AMPLICOR TESTS, pruebas Automatizadas en el analizador COBAS AMPLICOR $^{\mathrm{TM}}$ : COBAS AMPLICOR ${ }^{\mathrm{TM}}$ TESTS. Permiten cuantificar con alta exactitud la carga del virus en sangre (88).

Quantiplex ${ }^{\mathrm{TM}} \mathrm{HCV}$ RNA 2.0: prueba del ADN ramificado o bDNA para la determinación de la carga viral de Chiron Corporation (88).

LiPA (Line Probe Assay): permite la detección de los genotipos 1-6 del VHC mediante la hibridación reversa en tiras de membrana del producto amplificado por PCR con iniciadores derivados de la región 5'UTR del genoma viral (88).

Existen también ensayos de micropartículas paramagnéticas, que emplean péptidos sintéticos correspondientes a la cápsida y a la región c-100 y una proteína recombinante de C33c, con $91 \%$ de reactividad y test suplementario, en membrana de nitrocelulosa, que en la fase sólida utiliza antígenos recombinantes o péptidos sintéticos, de las regiones estructural y no estructural del virus $(89,90)$. 


\section{Gómez-Cordero, M Álvarez-García.}

\section{CONCLUSIONES.}

Los estudios clínicos muestran que los anticuerpos del núcleo de la proteína viral son altamente conservados y, además, presentan un epítopo inmunodominante en la región $\mathrm{N}$-terminal y que NS3 puede aparecer varias semanas antes que la seroconversión a anti-C100-3. Por lo tanto, los ensayos serológicos que incorporan una proteína de la nucleocápsida, así como NS3, son altamente específicos y sensibles y los más probables de convertirse en útiles marcadores de una infección por el VHC.

Como se puede observar en todos los métodos anteriormente descritos, a pesar de los avances alcanzados en el diagnóstico de esta etiología, el uso de proteínas recombinantes, péptidos sintéticos o ambos (ensayos de tercera generación), continúa siendo la única opción para el desarrollo de sistemas diagnósticos, debido a la imposibilidad actual de obtener antígenos naturales hasta tanto no se logre cultivar este virus. Sin embargo, se trata de eliminar las proteínas recombinantes, ya que en ocasiones pueden ser la causa de falsos positivos.

Los ensayos ELISA están basados en la mezcla de péptidos sintéticos, por ejemplo dos péptidos derivados de la región conservada $\mathrm{N}$-terminal de la proteína del núcleo del VHC. En los últimos años se están empleando en el diagnóstico péptidos quiméricos de diferente regiones del VHC.

\section{REFERENCIAS.}

1. Purcell R. The hepatitis $\mathrm{C}$ virus: overview. Hepatology 1997; 26 (Suppl 1): 11-4.

2. Lelbs A, Schwartz B. What's the latest on hepatitis C? Contemporary Pediatrics 1998; 15:39-46.

3. Colina R, Mogdasy MC, Cristina J, Uriarte MR. Caracterización molecular del virus de la hepatitis $\mathrm{C}$ en Montevideo-Uruguay. Rev Med Uruguay 2002; 18: 76-82. 4. MacCallun FO, Baver DJ. Homologous serum jaundice: transmission experiments with human volunteers. Lancet, 1944; 1:6222-7.

5. Havens WP. Experiment in cross immunity between infectious hepatitis and homologous serum jaundice. Proc
Soc Exp Biol Med, 1945; 59:148-53.

6. Prince AM, Brotman B, Grady GF, Kuhns WJ, Hazzi C, Levine RW, et al. Long-incubation post-transfusion hepatitis without serological evidence of exposure to hepatitis B virus. Lancet,1974; ii:241-6.

7. Choo QL, Kuo G, Weiner AJ, Overby LR, Bradley DW, Houghton M. Isolation of a cDNA clone derived from a blood-borne non-A, non-B viral hepatitis genome. Science, 1989; 244:359-62.

8. Krauledat PB, Scientific organizer. The identification of the Hepatitis $\mathrm{C}$ virus (HCV): Development of the first direct assay for viral Non-A, Non-B Hepatitis. Report of the Proceedings. First International Symposium Hepatitis C Virus. 1989 Sept 14-15, Rome, Italy. Ortho Diagnostic System Inc. Chirion Corporation, 1989.

9. Cuthbert JA. Hepatitis C: Progress and Problems. Clinical Microbiology Reviews, 1994; 7(4):505-32.

10. Purcell R. The hepatitis C virus: Overview. Hepatology 1997; 26(3), Suppl. 1:S11-S14.

11. Padrón G, Morales J. El virus de la Hepatitis C. En: Bases moleculares para el estudio de las hepatitis virales. Elfos Scientiae: La Habana, 1998; 161-84.

12. Picazo J, Fuertes A. Diagnóstico serológico de la hepatitis C. Protocolo de diagnóstico serológico clínico. Num 5. Innogenetics Diagnostica y Terapéutica, S.A. .

13. Liang J, Rehermann B, Seeff L, Hoofragle J. Pathogenesis Natural History, treatment, and prevention of hepatitis C. Ann Inter Med 2000; 132:296-305.

14. Bastie A, Pawiotsky JM, Roudot Thoraval F, Dhumeaux D. Infection par le virus de l'hepatite $\mathrm{C}$ epidemiologie. Pathol Biol Paris 1995; 43:674-80.

15. Alberti A, Chemello L, Benvegnu L. Natural history of hepatitis C. J Hepatol 1999; 31(Suppl 1):17-24.

16. Schiff E. Update in Hepatology. Ann J Med 1996; 132:4606.

17. Padrón GJ, Lemos G, Sánchez G, Arús E, Domínguez R, Chinea G, et al. Evaluación de un sistema para la detección de anticuerpos contra un antígeno sintético del core del virus de Hepatitis $\mathrm{C}$ y su prevalencia en donantes de sangre. Biotecnología Aplicada 1994; 11(2):165-70.

\section{Revista Biomédica}


Virus de la hepatitis $C$.

18. Rubio M, Rubio C, Nogués A, Manonelles A. Genotipos del virus de la hepatitis C. Estudio de 302 pacientes coinfectados por el virus de la inmunodeficiencia humana. Medicina Clínica 2001; 116: 650-1.

19. Rodríguez C. Actualización sobre hepatitis viral: etiología, patogenia, diagnóstico microbiológico y prevención. Rev Cubana Med Gen Integr, 2000, 16:574-85.

20. Koziel M. Immunology of viral hepatitis. Am J Med 1996; 100:98-109.

21. Farci P, Orgiana G, Purcell RH. Immunity elicited by Hepatitis C virus. Clin Exp Rheumatol 1995; 13 (Suppl 13):S9S12.

22. Takada A, Tsutsumi M, Okanoue T, Matsushima T, Komatsu M, Fujiyama S. Distribution of the different subtypes of hepatitis $C$ virus in Japan and the effects of interferon: a nationwide survay. J Gastroenterol Hepatol 1996; 11:201-7.

23. Rosa C, Osborne SJ, Griva S, Garetto F, Bonelli F, inventors; Sorin Biomedica Italia, assignee. HCV peptides and uses thereof. European Patent No. 0624597 A1. 1994; May/2.

24. Leahy D, Todd JA, Jolley ME, inventors; Baxter diagnostics Inc., assignee. Immunoassay for non-A non-B Hepatitis. International Publication Patent No. WO 92/22571. 1992b; Dec/23.

25. Miyakawa Y, Okamoto H, Mayumi M. Classifying Hepatitis C virus genotypes. Molecular Medicine Today (Reviews). 1995; 20-5.

26. Esteban JI. Diagnóstico y epidemiología molecular de la infección por HCV. Documentación extraída de la $1^{\text {a }}$ Reunión de Consenso: Manejo de las hepatitis crónicas víricas en pacientes con VIH, Organizada por la Fundación FIT en Madrid el día 6 de Octubre de 2000. En:Formación e información sobre tratamientos en el VIH/SIDA, Octubre 2000 .

27. Lunel F, Pawlotsky JM. Virus de l'hepatite C: diagnostic virologique. Pathol Biol Paris, 1995; 43(8): 681-90.

28. Yatsuhashi H, Inove O, Koga M, Nagataki S, Mizuno K, Kolberg J, et al. Comparison of hepatitis $\mathrm{C}$ virus markers in patients with NANB hepatitis. J Virol Meth, 1992; 37:13-22.

29. Habets JA, Boender J, inventors; Akzo Nobel N.V., assignee. Hepatitis $\mathrm{C}$ virus (HCV) non-structural-3 peptides, antibodies thereto and methods for the detection of HCV. International Publication Patent No. WO 94/13699. 1994; Jun/ 23.

30. Dusheinko G, Simmonde P. Sequence variability of Hepatitis $\mathrm{C}$ virus and the clinical relevance. J Viral Hepat 1994; 1:3-15.

31. Molinari JA. Hepatitis C virus infection. Dent Clin N A 1996; 40: 309-25.

32. Neddermann P, Tomei L, Steinkuhler C, Gallinari P, Tramontano A, DeFrancesco R. The nonstructural proteins of the hepatitis $\mathrm{C}$ virus: Structure and functions. Biol Chem 1997; 378: 469-76.

33. Jin L, Peterson DL. Expression, isolation, and characterization of the hepatitis $\mathrm{C}$ virus ATPase/RNA helicase. Arch Biochem Biophys 1995; 323:47-53.

34. Simmonds P, Yap L, Pike IA, inventors; Murex diagnostics LTD, assignee. Common Services Agency. Hepatitis C virus type 4, 5 and 6. European Patent No. WO 9425602 A1 941110. 1994; Nov/11.

35. Yao N, Hesson T, Cable M, Hong Z, Kwong AD, Le HV, et al. Structure of the hepatitis $\mathrm{C}$ virus RNA helicase domain. Nat Structural Biol 1997; 4:463-7.

36. Robinson JW, Rosas M, Guzmán F, Patarroyo ME, Moreno A. Comparison of prevalence of anti-hepatitis C virus antibodies in differing South American populations. J Med Virol 1996; 50:188-92.

37. Ray R, Khanna A, Lagging LM, Meyer K, Choo QL, Ralston R, et al. Peptide immunogen mimicry of putative E1 glycoprotein-specific epitopes in hepatitis $\mathrm{C}$ virus. J Virol 1994; 68:4420-6.

38. Zhang ZX, Sonnerborg A, Sallberg M. Antigenic structure of the hepatitis $\mathrm{C}$ virus envelope 2 protein. Clin Exp Immunol, 1994; 98:382-87.

39. Weiner AJ, Houghton M, inventors; Chirion Corporation, assignee. Conserved motif of hepatitis $\mathrm{C}$ virus E2/NS1 region. Patent No. WO 9426306 A1 941124. 1994; Nov/11.

40. Zhang ZX, Chen M, Sonnerborg A, Sallberg M. Antigenic structure of the complete nonstructural (NS2) 2 and 5 proteins of Hepatitis $\mathrm{C}$ virus (HCV): anti - HCV NS2 and NS5 antibody reactivities in relation to $\mathrm{HCV}$ serotype, presence of HCV RNA, and acute HCV infection. Clin Diagn Lab Immunol, 1994; 1(3):290-4.

Vol.14/No.4/Octubre-Diciembre, 2003 


\section{Gómez-Cordero, M Álvarez-García.}

41. Kanai A, Tanabe K, Kohara M. Poly(U) binding activity of hepatitis C virus NS3 protein, a putative RNA helicase. FEBS Lett. 1995; 376(3):221-4.

42. Hong Z, Ferrari E, Wright J, Chase R, Risano C, Seelig G, et al. Enzymatic characterization of hepatitis C virus NS3A4A complexes expressed in mammalian cells by using the herpes simplex virus amplicon system. J Virol 1996; 70:42618.

43. Hang J, Choe J, inventors; Chiron Corporation, assignee. HCV NS3 protein fragments having helicase activity and improved solubility. US/US Patent No. WO 9712043 A2 970403. 1997; April/3.

44. Ishido S, Fujita T, Hotta H Complex formation of NS5B with NS3 and NS4A proteins of Hepatitis C virus. Biochem Biophys Res Commun 1998; 244: 35-40.

45. Gwack Y, Kim DW, Han JH, Choe J. Characterization of RNA binding activity and RNA helicase activity of hepatitis C virus NS3 protein. Biochem Biophys Res Commun 1996; 225:654-9.

46. Borowski P, Heiland M, Oehlmann K, Becker B, Kornetzky $\mathrm{L}$, Feucht $\mathrm{H}$, et al. Non-structural protein 3 of hepatitis $\mathrm{C}$ virus inhibits phosphorylation mediated by cAMPdependent protein kinase. Eur J Biochem 1996; 237: 611-8.

47. Simmonds P, Rose KA, Graham S, Chan SW, McOmish F, Dow BC, et al. Mapping of serotype-specific, immunodominant epitopes in the NS-4 region of hepatitis $\mathrm{C}$ virus (HCV): Use of type-specific peptides to serologically differentiate infections with HCV types 1, 2, and 3. J Clin Microbiol 1993; 31:1493-503.

48. Lohmann V, Korner F, Herian U, Bartenschlager R. Biochemical properties of hepatitis $\mathrm{C}$ virus NS5B RNAdependent RNA polymerase and identification of amino acid sequence motifs essential for enzymatic activity. J Virol 1997; 71:8416-28.

49. Rice C III, Kolykhalov AA, inventors; Washington University, assignee. Novel 3 'terminal sequence of hepatitis $\mathrm{C}$ virus genome and diagnostic and therapeutic uses thereof. Patent No. WO 9708310 A1 970306. 1997; Jun/3.

50. Tanaka T, Kato N, Cho MJ, Shimotohno K. A novel sequence found at the 3' terminus of the Hepatitis $\mathrm{C}$ virus genome. Biochem Biophys Res Commun 1995; 215:744-9.

51. Kolykhalov AA, Feinstone SM, Rice CM. Identification of a highly conserved sequence element at the 3 'terminus

\section{Revista Biomédica}

of hepatitis C virus genome RNA. J Virol 1996; 70:3363-71.

52. Tanaka T, Kato N, Cho MJ, Sugiyama K, Shimotohno K. Structure of the 3 ' terminus of the hepatitis $\mathrm{C}$ virus genome. J Virol 1996; 70: 3307-12.

53. Shukla DD, Hoyne PA, Ward CW. Evaluation of complete genome sequences and sequences of individual gene products for the classification of hepatitis $C$ viruses. Arch Virol 1995; 140:1747-61.

54. Mondelli MU, Cerino A, Bono F, Cividini A, Maccabruni A, Arico M, et al. Hepatitis C virus (HCV) core serotypes in chronic HCV infection. Clin Microbiol 1994; 32:2523-7.

55. Zeuzem S, Ruster B, Lee JH, Stripf T, Roth WK. Evaluation of a reverse hybridization assay for genotyping of hepatitis C virus. J Hepatol 1995; 23: 654-61.

56. Matsubara T, Sumazaki R, Shin K, Nagai Y, Takita H. Genotyping of hepatitis $\mathrm{C}$ virus: coinfection by multiple genotypes detected in children with chronic posttransfusion hepatitis C. J Pediatr Gastroenterol Nutr 1996; 22: 79-84.

57. Lee DS, Sung YC, Whang YS. Distribution of HCV genotypes among blood donors, patients with chronic liver disease, hepatocellular carcinoma, and patients on maintenance hemodialysis in Korea. J Med Virol 1996; 49: 55-60.

58. Takada A, Tsutsumi M, Zhang SC, Okanoue T, Matsushima T, Fujiyama S, et al. Relationship between hepatocellular carcinoma and subtypes of hepatitis $\mathrm{C}$ virus: a nationwide analysis. J Gastroenterol Hepatol 1996; 11: 1669.

59. Bukh J, Purcell RH, Miller RH. Sequence analysis of the core gene of 14 hepatitis $\mathrm{C}$ virus genotypes. Proc Natl Acad Sci USA 1994; 91:8239-43.

60. Schreier E, Roggendorf M, Driesel G, Hohne M, Viazov $\mathrm{S}$. Genotypes of hepatitis $\mathrm{C}$ virus isolates from different parts of the world. Arch Virol (Suppl) 1996; 11:185-93.

61. Maertens G, Stuyver L, inventors; Innogenetics N.V., assignee. New sequences of hepatitis $\mathrm{C}$ virus genotypes and their uses as prophylactic, therapeutic, and diagnostics agents. Patent No. WO 9613590 A2 960509. 1996: May/9.

62. Yoshihara N. ELISA for diagnosis of infections by viruses. Nippon Rinsho 1995; 53: 2277-82. 
Virus de la hepatitis $C$.

63. Mishiro S, Hoshi Y, Takeda K. Non-A, non-B hepatitis specific antibodies directed at host-derived epitope. Implication for an autoimmune process. Lancet 1990; 336:1400-3.

64. Soffredini R, Rumi M, Lampertico, Aroidi A, Tarantino A, Ponticelli C, Colombo M. Increased detection of antibody to hepatitis $\mathrm{C}$ virus renal transplant patients by thirdgeneration assays. Am J Kidney Dis 1996; 28:437-40.

65. Rosa C, Caborne S, Garetto F, Griva S, Rivella A, Calabresi $\mathrm{G}$, et al. Epitope mapping of the NS4 and NS5 gene products of hepatitis C virus and the use of a chimeric NS4-NS5 synthetic peptide for serodiagnosis. J Virol Methods 1995; 55:219-32.

66. Gretch DR. Diagnostic test for hepatitis C. Hepatology, 1997; 263 (Suppl) 43S-47S.

67. Donegan E, Wright TL, Roberts J, Ascher NL, Lake JR, Neuwald P, et al. Detection of hepatitis C after liver transplantation. Four serologic tests compared. Am J Clin Pathol 1995; 104: 673-9.

68. Farma E, Boeri E, Morsica G, McDermott J, Soldini L, Repetto CM, et al. "Single step" PCR with a sensitivity similar to nested PCR for the detection of hepatitis C virus RNA. Clin Exp Rheumatol 1995; 13 (Suppl): S59-61.

69. Dixit V, Quan S, Martin P, Larson D, Brezina M, Dinelio R, et al. Evaluation of a novel serotyping system for hepatitis $\mathrm{C}$ virus: strong correlation with standard genotyping methodologies. J Clin Microbiol 1995; 33:2978-83.

70. Tisminetzky S, Gerotto M, Pontisso P, Chemello L, Prescott LE, Rose KA, et al. Comparison of genotyping and serotyping methods for the identification of hepatitis $C$ virus types. J Virol Meth 1995; 55:303-7.

71. Enzymun-Test ${ }^{\circledR}$ Anti-HCV (No. 15557327). Boehringer Mannheim Immunodiagnostics 1994; ES 700/ES 607/ES 600/ ES 300 .

72. MONOLISA anti-HCV Detection kit for antibodies to $\mathrm{HCV}$ (Hepatitis $\mathrm{C}$ virus or related variants) in human serum by enzyme immunoassay. Sanofi Diagnostics Pasteur, S.A. 1996; code: 806719, 03/96.

73. Hepatitis C virus. UBI HCV EIA 4.0. Beijing United Biomedical Co., Ltd., Beijing, PR China. U.S. patent No. 5106726, Australia patent No. 635124. 81964. 1994; Jun/20.
74. Kashiwakuma T, Hasegawa A, Kajita T, Takata A, Mori $\mathrm{H}$, Ohta Y, et al. Detection of Hepatitis C virus specific core protein in serum of patients by a sensitive fluorescence enzyme immunoassay (FEIA). J Immunol Meth 1996; 28, 190(1): 79-89.

75. Tanaka T, Lau JY, Mizokami M, Orito E, Tanaka E, Kiyosawa K, et al. Simple fluorescent enzyme immunoassay for detection and quantification of hepatitis $\mathrm{C}$ viremia. $\mathrm{J}$ Hepatol. 1995; 23: 742-5.

76. Orito E, Mizokami M, Tanaka T, Lau JYN, Suzuki K, Yamauchi M, et al. Quantification of serum hepatitis $\mathrm{C}$ virus core protein level in patients chronically infected with different hepatitis C virus genotypes. Gut 1996; 39:876-80.

77. Tanaka E, Kiyosawa K, Matsumoto A, Kashiwakuma T, Hasegawa A, Mori H, et al. Serum levels of hepatitis C virus core protein in patients with chronic hepatitis $\mathrm{C}$ treated with interferon alfa. Hepatology 1996; 23:1330-3.

78. Ornopia GL, Kuramoto K. Detection of anti-hepatitis C virus using chemiluminescence. J Viral Hepat 1995; 2:215-9.

79. AxSYm HCV®. Antígenos codificados del virus de la hepatitis C. Abbott System. 1995.

80. ABBOTT HCV EIA 3.0. Hepatitis $\mathrm{C}$ virus encoded antigen (Recombinant c100-3, HC-34, HC-43, NS5). Enzyme immunoassay for the qualitative detection of antibody to hepatitis $\mathrm{C}$ virus (Anti-HCV) in human serum or plasma. ABBOTT Diagnostics Division, Germany, 1995.

81. Al Meshari K, Alfurayh O, Al Ahdal M, Qunibi W, Kessie $\mathrm{G}$, De Vol E. Hepatitis C virus infection in hemodialysis patients: comparison of two new hepatitis $\mathrm{C}$ antibody assays with a second-generation assay. J Am Soc Nephrol 1995; 6:1439-44.

82. Boston Biomedica, Inc. Anti-HCV Low titer performance panel (PVH103) and Anti-HCV Mixed titer performance panel (PVH204). W. Bridgewater, 1995.

83. Murex anti-HCV (Version III). Enzyme immunoassay for the detection of antibodies to hepatitis $\mathrm{C}$ virus (HCV). VK47/ 48, Bronidox ®, Henkel Chemical Co., 1994.

84. UMELISA HCV. Para la detección de anticuerpos al virus de la hepatitis $\mathrm{C}$ en suero humano, plasma o sangre seca sobre papel de filtro. Centro de Inmunoensayo, Cuba, 2001. 


\section{Gómez-Cordero, M Álvarez-García.}

85. UMELOSA HCV Cualitativo. Centro de Inmunoensayo, Cuba, 2002.

86. Bernstein D. Diagnosis and management of hepatitis C. Gastroenterology Clin Mgmt [Serial on line] $2001 \mathrm{Feb}$ [Cited 2002 Feb 2]: 1(1): [28 screens] available from: url: http:// www.medscape.com/MedScape/gcstro/Clinicalmgmt/ CM.v01/public/index-CM.v01.html.

87. Nasti G, Di Genaro G, Tavio M, Cadorn L, Tedeschi R, Talamini, et al. Cronic hepatitis C in HIV infection: fecsibility and sustained efficacy of therapy with interferon alfa- $2 b$ and rivabirin. AIDS 2001; 15:1783-7.

88. Córdoba J, Olaso V, Molina JM, López B, Argüello L, Ortiz V, et al. Análisis comparativo de la carga viral mediante bDNA HCV RNA-2.0 y Amplicor HCV Monitor, en pacientes infectados por el virus de la hepatitis C. Enf Infec Microbiol 2000; 18: 6-11.

89. Leahy D, Kink J, Byrne R, Shah D, Preisel B, Laska S, et al. Improved serologic detection of hepatitis $\mathrm{C}$ virus with a paramagnetic microparticle assay using multiple antigenic sequences. Transfusion 1992; 32:548-53.

90. Todd J, Kink J, Leahy D, Preisel Simmons B, Laska S, Wolff $\mathrm{P}$, et al. A novel semi-automated paramagnetic microparticle based enzyme immunoassay for hepatitis $\mathrm{C}$ virus: Its application to serologic testing. J Immunoassay 1992; 13:393-410.

\section{Revista Biomédica}

